\title{
Assessment of Pathogen Reduction Potential of an Anaerobic Digester containing Winery Wastewater
}

\author{
Vincent I. Okudoh, Benjamin I. Okeleye, Ronny M. Ngwe and Seteno K.O. Ntwampe
}

\begin{abstract}
In this study, assessment of the pathogenic bacteria reduction capacity of an anaerobic digester (AD) containing winery wastewater (WWW) was carried out. Samples were collected from a winery drainage system (influent) and a bioreactor after digestion (effluent) at the Agricultural Research Council (ARC), Stellenbosch, South Africa. Qualitative analysis was by means of $\mathrm{pH}$, optical density (OD) and most probable number (MPN) techniques. The isolates were identified using biochemical and polymerase chain reaction (PCR) methods. Results showed an increase in pH from 6.71 to 6.97 with MPN index per $100 \mathrm{~mL}$ reduction of presumptive coliforms from $>1,100$ to 313.3 after digestion at $95 \%$ confidence interval (CI), respectively. A $3 \mathrm{log}$ removal efficiency (99.9\%) of Escherichia coli, Salmonella spp., Azomonas spp. and Aeromonas hydrophila was achieved after 30 days retention time in the bio-digester. The significant reduction of these surrogate pathogens during the process of biogas production is of importance to mitigate against environmental health concerns.
\end{abstract}

Keywords-Anaerobic digestion, biogas, methanogens, pathogen reduction

\section{INTRODUCTION}

Of all challenges faced by many countries of the world today, none has become more urgent than improper waste management practices and depletion of natural resources aggravated by increasing population and urbanization [1]. Domestic and industrial wastes contain toxicants and pathogenic microorganisms that are detrimental to ecosystem and human life [2]. Anaerobic digestion (AD) has been reported to be effective in wastes treatment with plausible economic potential of the biogas produced as a source of renewable energy and fertilizer [3].

Waste treatments consist of the removal of microorganisms, organic and inorganic components, using aerobic or AD oxidation ponds including trickling bed filters subsequent to filtration for removal of residual pollutants, and disinfection procedures using chlorine, UV radiation, or ozone for deactivation of microorganisms [2], [4]. All the downstream processes are highly dependent on the functionality of the $\mathrm{AD}$, as a primary process for organic matter reduction. $\mathrm{AD}$ process is a fermentation process, through the action of anaerobes; that

All Authors are with Bioresource Engineering Research Group (BioERG), Department of Biotechnology, Faculty of Applied Sciences, Cape Peninsula University of Technology, Keizersgracht and Tennant Street, Zonnebloem, P.O. Box 652, Cape Town, 8000, South Africa. decompose the decomposable organic matter in low redox potential, in a close system, without the supply of oxygen. Bacteria are therefore directly or indirectly linked in a symbiotic way; where the product of one provides the substrate for others. The four basic processes involved in anaerobic conversion of organic matter are hydrolysis, acidogenesis, acetogenesis and methanogenesis as shown in Fig. 1.

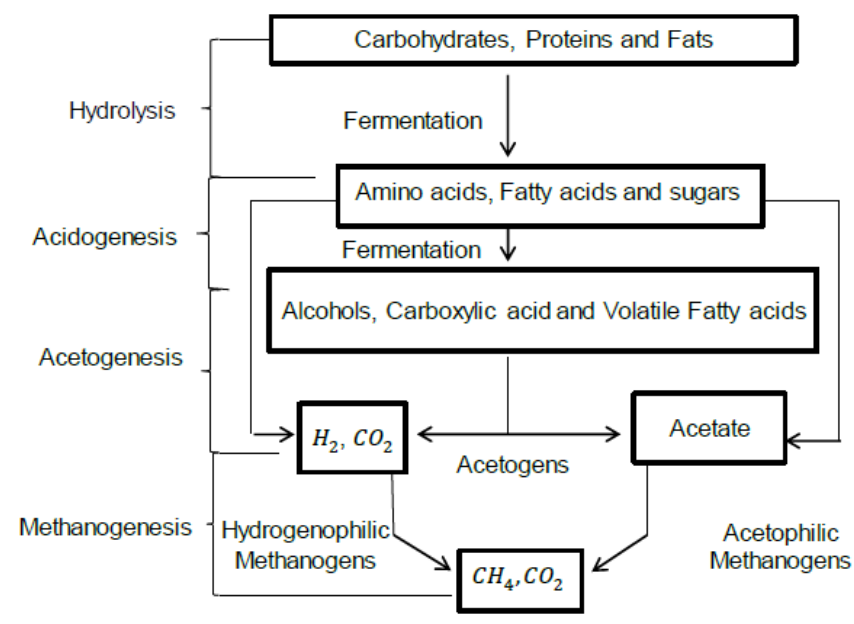

Fig. 1 Biochemical stages in anaerobic digestion [2], [5]

The survival of microbes in $\mathrm{AD}$ depends on this interaction, and the environmental factors in which they are exposed. Bacteria are classified into different groups, according to their ability to use the organic matter available, at varying temperature, $\mathrm{pH}$ range, and salinity. $\mathrm{AD}$ operates well at meso and thermophilic conditions within a $\mathrm{pH}$ range near neutral [5]. A low redox potential environment is required to stabilize growth of facultative anaerobes through the use of organic acids available. Microbes that are involved in the hydrolysis of organic matter can produce substrates suitable for acidogens. The acidogens also yield products that favoured the growth of acetogens that ferment organic acids and lower dissolved hydrogen $\left(\mathrm{H}_{2}\right)$ gas concentration to create a suitable environment for methanogens for $\mathrm{H}_{2}, \mathrm{CO}_{2}$ and acetic acid consumption for the production of methane gas [1]. In $\mathrm{AD}$, the proliferation of pathogens is high, as most constitute the sludge used in $\mathrm{AD}$ technologies.

Pathogens are microbes that have the ability to cause disease in hosts. They have a direct interaction with the surrounding environment, and represent a risk to plants and animals through oral and cutaneous pathways. Validation and efficacy of pathogen reduction or removal in the $\mathrm{AD}$ is therefore vital to accomplish a safe environment [6]. 


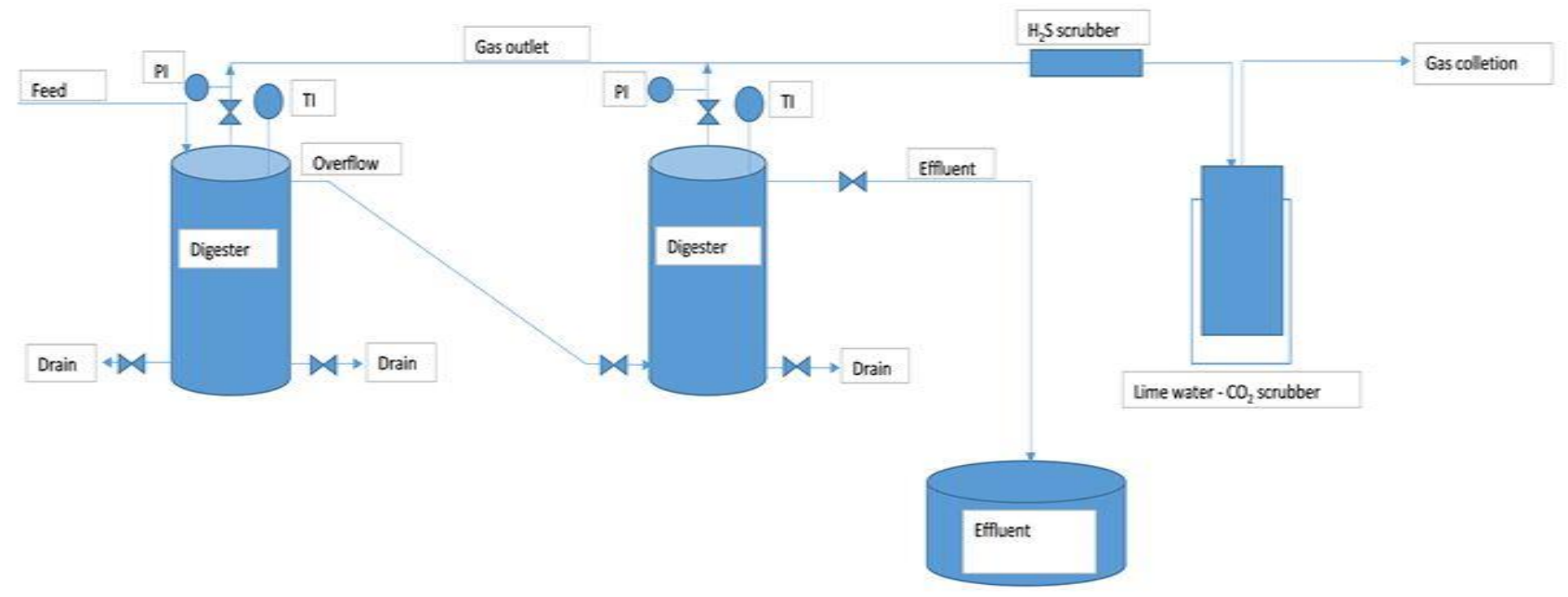

Fig. 2. Design of the anaerobic digester used for biogas production.

About $35 \%$ of municipal and $13 \%$ of agricultural waste were produced in the Western Cape Province South Africa in the year 2014. The indiscriminate disposal of untreated winery wastewater (WWW) directly into the environment by some winery farms constitutes a danger to public health due to its potential to support proliferation of pathogenic bacteria which can result in the outbreak of emerging diseases [7]. A technique that will effectively facilitate biogas production from the winery waste, reduce the density of microbial pathogen proliferation, as well as to contribute to the improvement of soil fertility used for cultivar growth and crop's yield, is therefore needed. To the best of our knowledge, there is no known study that reported on the pathogen surveillance of the winery wastewater generated on Agricultural Research Council (ARC), Nietvoorbij farm, Stellenbosch South Africa. The present study aims to measure the rate of reduction in the density of some specific pathogenic bacteria and to identity the microorganisms involved in AD containing WWW for biogas production.

\section{MATERIALS AND METHODS}

\section{A. Design and Construction of Anaerobic Digester}

Little Green Monster anaerobic digesters were commercially purchased from Sustainable Engineering Solutions (Pty) Ltd, and used in the $\mathrm{AD}$ plant design and construction in the Biotechnology and Chemical Engineering Departments, Cape Peninsula University of Technology. The AD was designed for the production of biogas (methane) and built at proximity to the winery wastewater (WWW) drainage system at Agricultural Research Council (ARC), Nietvoorbij farm, Stellenbosch South Africa (Fig. 2 and 3).

\section{B. Sample Collection and Preparation}

Samples were collected from the ARC winery wastewater (WWW) drainage system (influent) and the AD (effluent) designed for post organic matter reduction. About $120 \mathrm{~mL}$ of wastewater samples were collected between 6th and 20th April 2016, in triplicate, into $250 \mathrm{~mL}$ clean glass bottles and stored in ice box before transported to the Biotechnology laboratory for analysis. The samples were analyzed within $16 \mathrm{~h}$ of collection and under aseptic conditions according to standard methods for the examination of water and wastewater [8].

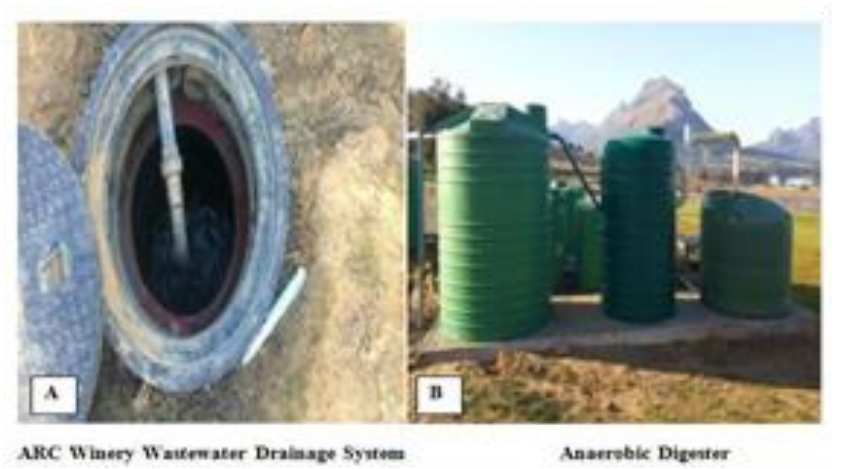

Fig. 3. A, Winery drains (Influent) and B, AD (effluent) at ARC

\section{Physicochemical Analysis}

The physicochemical analysis was done according to the method of Igbinosa and Okoh [9], with some modifications. The $\mathrm{pH}$ analysis was carried out by means of standard $\mathrm{pH}$ meter (YSI, USA). About $60 \mathrm{~mL}$ of WWW was measured into a 100 $\mathrm{mL}$ beaker and stirred before measuring the $\mathrm{pH}$. A spectrophotometer adjusted at $600 \mathrm{~nm}$ wavelength was used to determine the optical density or turbidity of the samples. Distilled water was used as a blank and the sample readings were recorded.

\section{Multiple-Tube Fermentation (MTF) Assay}

Assay for faecal contamination and total coliforms were conducted with multiple-tube fermentation (MTF) technique and the results were expressed in terms of the most probable number (MPN), which provides statistical estimate of total coliforms present in the sample. A series of double strength Brilliant Green Bile (BGB) broth tubes were inoculated with 0.1 $\mathrm{mL}, 1.0 \mathrm{~mL}$, and $10.0 \mathrm{~mL}$ dilutions of the WWW sample in triplicate. A positive presumptive test showed production of gas in the Durham tube after $24 \mathrm{~h}$ of incubation at $37^{\circ} \mathrm{C}$. Tubes with positive presumptive tests were subjected to confirmation test in 3 single strength BGB broth (and peptone water) containing Durham tubes. A positive confirmation tube was accompanied by formation of a gas in single strength BGB broth within $48 \mathrm{~h}$ 
10th Int'l Conference on Advances in Science, Engineering, Technology \& Healthcare (ASETH-18) Nov. 19-20, 2018 Cape Town (South Africa) at $42{ }^{\circ} \mathrm{C}$. From a positive sample, $100 \mu \mathrm{L}$ was spread onto the surface of a Violet Red Bile (VRB) agar plate and incubated at $37{ }^{\circ} \mathrm{C}(24 \mathrm{~h})$ for the enumeration of coliforms [10].

\section{E. Cultural Counts and Preliminary Identification}

Tenfold serial dilution up to $10^{-6}$ of the WWW was prepared in sterile water. Each dilution was plated onto Nutrient Agar (NA) plates and incubated at $37{ }^{\circ} \mathrm{C}$ for $24 \mathrm{~h}$. The diversity of colony morphologies on NA was compared across the different dilution treatments and the number of colony-forming unit per $\mathrm{mL}$ (CFU/ $\mathrm{mL}$ ) was determined after 2 days. Twelve colonies were randomly chosen from each plate and colony morphology was described based on size, elevation, form, and pigmentation. Gram stain, Kinyoun stain, and biochemical tests; i.e. carbohydrate alcohol fermentation, indole production, starch hydrolysis, methyl red and Voges proskauer tests, gelatin hydrolysis, oxidation fermentation production, lipid hydrolysis, litmus milk, lysine decarboxylase, urease test, citrate utilization and nitrate reduction were used as presumptive identification methods for pure isolates.

The log removal value (LRV) was calculated using the following equation 1 :

$$
L R V=\log 10 \frac{\text { Influent Pathogen Concentration }}{\text { Effluent Pathogen Concentration }}
$$

\section{F. Molecular Identification Using PCR}

Deoxyribonucleic acid (DNA) extracted from a 10-12 h old isolate was used for polymerase chain reaction (PCR) analysis according to the method reported by Deshmukh et al. [10]. Briefly, two to three colonies suspended in $200 \mu \mathrm{L}$ of Lysis buffer with $0.3 \mathrm{~g}$ of sterile glass beads were vortexed $(3 \mathrm{~min}$ ) and incubated in water-bath at $37{ }^{\circ} \mathrm{C}$ for $1 \mathrm{~h}$. After cooling and centrifugation at $10000 \mathrm{x} \mathrm{rpm}(5 \mathrm{~min})$ the supernatant was treated with isopropanol and incubated for $10 \mathrm{~min}$. The pellet was suspended in Tris-EDTA (TE, $400 \mu \mathrm{L}$ ) and Bovine Pancreatic Ribonuclease A (RNase A, $3 \mu \mathrm{L}$ ) after centrifugation, subsequent to incubation for $5 \mathrm{~min}\left(37^{\circ} \mathrm{C}\right)$. The extracted DNA was precipitated with $100 \%$ ethanol $(1 \mathrm{~mL})$ and the pellet was further washed twice with $70 \%$ ethanol before re-suspension in $50 \mu \mathrm{L}$ of TE prior to PCR analysis. The PCR assays were carried out using a MyCycler ${ }^{\mathrm{TM}}$ thermal cycler, with a reaction mixture of $2.5 \mu \mathrm{L}$ of DNA sample, $2.5 \mu \mathrm{L}$ of $10 \mathrm{x}$ amplification buffers, $0.5 \mu \mathrm{L}$ of $20 \mu \mathrm{M}$ of forward and reverse primers $16 \mathrm{~F} 27$ (5'-CCAGAGTTTGATCMTGGCTCAG-3') and 16R1488 (5'-AGAGTTTGATCMTGGCTCAG-3'), $0.5 \mu \mathrm{L}$ of $20 \mathrm{mM}$ solution of four dNTPs, $18.375 \mu \mathrm{L}$ of $\mathrm{H}_{2} \mathrm{O}, 0.125 \mu \mathrm{L}$ of $1-5$ units thermostable DNA polymerase. The cycle number was set according to 1 cycle with denaturation for $2 \min \left(95{ }^{\circ} \mathrm{C}\right), 35$ cycles with denaturation for $1 \mathrm{~min}\left(95^{\circ} \mathrm{C}\right)$, annealing for $30 \mathrm{sec}$ $\left(50{ }^{\circ} \mathrm{C}\right)$ and polymerization for $2 \min \left(72{ }^{\circ} \mathrm{C}\right)$. About $5-10 \mu \mathrm{L}$ of the mixture and molecular marker was withdrawn to visualize the DNA under Ultra Violet (UV) light through agarose gel with ethidium bromide.

\section{A. Physicochemical Characterization}

Winery wastewater (WWW) samples collected from the inlet (influent) and outlet (effluent) of an anaerobic digester was analyzed for their acidity and basicity $(\mathrm{pH})$. The influent water indicated $\mathrm{pH}$ of $6.73,6.71$ and 6.69 (3 samples). The samples were acidic due to the presence of organic acids found in pressed grapes (malic and tartaric acid) that lowered the $\mathrm{pH}$ of the wastewater used during the process of cleaning the materials in the winery farm [11]. However, the effluent showed an increase in $\mathrm{pH}$ to 6.95 (sample 1) and 6.98 (sample 2 and 3) after digestion. This could be as a result of acetogenesis, which is the acidic substrate conversion of bacteria that produced ammonia; hence, an increase in the $\mathrm{pH}$ close to neutral $(\mathrm{pH}$ 7.00) [12]. The spectrophotometric analysis of turbidity of the WWW revealed that light was absorbed more in the influent (1.7-1.88) than in effluent (1.45-1.57) samples as shown in Fig. 4 and 5. This gave an indication of high organic matter concentration in the influent and a decrease in the bacteria density of the effluent. The turbidity at the exit port of the anaerobic digester decreased due to the possible inhibitory products generated during the AD process. The optical density therefore showed the reduction of suspended solids and matter contributing to the organic load in the effluent port. This corroborates the differentiation observed in the bacteria cell concentration for the influent and effluent in this study. Generally, high cell concentration of a sample, results in high turbidity [13], albeit suspended matter is also known to contribute to high turbidity, therefore the $\mathrm{AD}$ bed can alter a bio-filter.

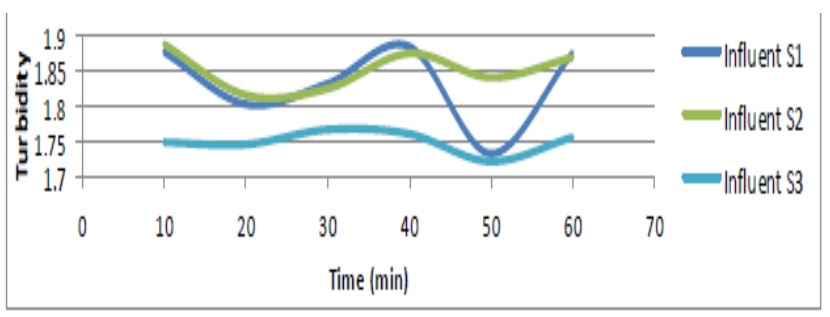

Fig. 4 Turbidity of the influent

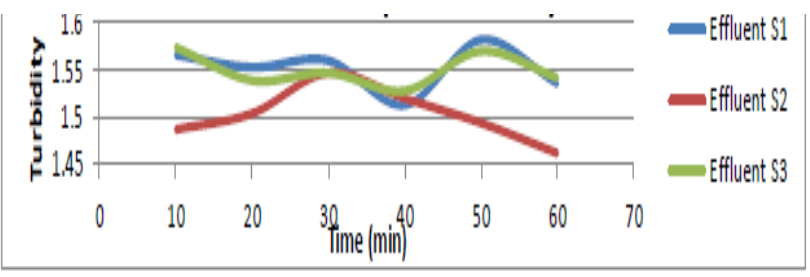

Fig. 5. Turbidity of the effluent

\section{B. Most Probable Number of Coliforms}

Most probable number (MPN) index per $100 \mathrm{~mL}$ reduction of presumptive coliforms was recorded from $>1,100$ (influent) to 313.3 (effluent) after digestion at $95 \%$ confidence interval (CI). One of the common target microorganisms that confirmed faecal contamination in water is E. coli. MPN of 376 per 100 $\mathrm{mL}$ (peptone water) and 349 per $100 \mathrm{~mL}$ (single strength BGB agar) were detected in the influent from the presumptive 


\begin{tabular}{|c|c|c|c|c|c|c|c|c|c|c|c|}
\hline & & II $1^{*}$ & II 2 & II 3 & II 4 & II 5 & EI 6 & EI 7 & EI 8 & EI 9 & E. coli \\
\hline & Glucose & - & - & + & + & + & + & - & + & + & + \\
\hline \multirow{4}{*}{$\begin{array}{l}\text { Carbohydrate } \\
\text { alcohol } \\
\text { fermentation }\end{array}$} & Sucrose & - & - & + & - & - & + & - & + & + & - \\
\hline & Maltose & - & - & + & + & + & + & - & + & + & + \\
\hline & Xylose & - & - & - & + & + & - & - & - & - & + \\
\hline & Gas & No & No & Yes & No & Yes & Yes & No & Yes & Yes & Yes \\
\hline Starch agar & & - & - & + & - & - & + & - & - & - & - \\
\hline \multirow[t]{2}{*}{ MRVP } & MR & - & - & + & + & + & - & + & - & - & + \\
\hline & VP & - & - & - & - & - & - & - & - & - & - \\
\hline \multirow[t]{2}{*}{$\mathbf{O F}$} & Aerobe/Facultative & + & + & + & + & + & + & - & + & + & + \\
\hline & anaerobe & - & - & - & - & - & - & - & - & - & - \\
\hline Citrate & & + & + & - & - & - & - & + & + & + & - \\
\hline Lipid & & - & - & + & - & - & - & - & - & - & - \\
\hline Litmus & & Acid & Acid & Alkaline & Alkaline & ACR & APR & Alkaline & Acid & Acid & ACR \\
\hline Nitrate & & - & - & + & + & + & - & + & + & + & + \\
\hline Gelatin & & - & - & + & - & - & - & - & - & - & - \\
\hline Urea & & - & - & - & - & - & - & - & - & - & - \\
\hline Lysine & & - & - & + & + & - & + & - & - & - & - \\
\hline Indole & & - & - & + & - & + & - & - & - & - & + \\
\hline
\end{tabular}

*II, Influent Isolate; EI, Effluent Isolate; ACR, Acid Curd Reduction; APR, Alkaline Peptonization Reduction; +, Positive; -, Negative

coliforms test in VRB agar plate counts as shown in Table I. These findings revealed that the drainage water from the winery farm had been contaminated with enteric pathogens, which is an indication of possible faecal contamination or poor water sanitation [10], similar to the study conducted by Kayembe et al. [14]. It was observed that $E$. coli was only identified in the influent and not in the effluent, which confirmed the reduction of $E$. coli colonies during the anaerobic process.

TABLE I: COMPARATIVE PRESUMPTIVE COLIFORMS TO THE MPN TABLE

\begin{tabular}{cccc}
\hline $\begin{array}{c}\text { Influent } \\
\text { samples }\end{array}$ & $\begin{array}{c}\text { MPN index per } \\
\mathbf{1 0 0} \mathbf{~ m L}\end{array}$ & \multicolumn{2}{l}{ 95\% confidence limits } \\
\cline { 3 - 4 } & & Lower & Upper \\
\hline 1 & $>1,100$ & $>150$ & $>4,800$ \\
2 & $>1,100$ & $>150$ & $>4,800$ \\
3 & $>1,100$ & $>150$ & $>4,800$ \\
Effluent & & & \\
samples & & 36 & 1,300 \\
\hline 1 & 240 & 71 & 2,400 \\
2 & 460 & 36 & 1,300 \\
\hline
\end{tabular}

\section{Viable Bacteria Counts and Biochemical Test}

Bacteria in the ten-fold serially diluted WWW were enumerated on both pour and spread agar plates and expressed as colony forming unit per $\mathrm{mL}$ (CFU/ $\mathrm{mL}$ ). Nine (9) colonies were randomly selected, from both influent and effluent, during spread plate (SP) and pour plate (PP) counts. Presumptive bacteria isolates were detected by means of staining techniques and biochemical reactions (Table III). These are the recommended methods to identify and enumerate frank and opportunistic bacterial pathogens in water and biofilms [15]. As shown in Table II, effluent bacterial concentration (EBC) was reduced to $2.5 \times 10^{5}$ (SP) and $2.3 \times 10^{5}(\mathrm{PP})$ from $6.7 \times 10^{5}(\mathrm{SP})$ and $7.6 \times 10^{5}(\mathrm{PP})$ of influent bacterial concentration (IBC) at $10^{-4}$ dilution factor (DF), respectively. This is in line with the study conducted by Di Pinto et al. [6], who reported the isolation of Aeromonas spp. in the seafood as a result of water contamination. They were isolated in $70.3 \%$ of seafood, which in recent years has received increasing attention as an agent of food-borne diseases in healthy people.

TABLE II: BACTERIAL COLONY COUNTS AND CONCENTRATION

\begin{tabular}{|c|c|c|c|c|c|c|}
\hline \multirow[b]{2}{*}{ DF* $^{*}$} & \multicolumn{3}{|c|}{ SP* (CFU/ mL) } & \multicolumn{3}{|c|}{ PP $(\mathrm{CFU} / \mathrm{mL})$} \\
\hline & $10^{-2}$ & $10^{-3}$ & $10^{-4}$ & $10^{-2}$ & $10^{-3}$ & $10^{-4}$ \\
\hline IS & 382 & 89 & 79 & 331 & 163 & 71 \\
\hline $1^{*}$ & & & & & & \\
\hline IS 2 & 374 & 101 & 73 & 313 & 152 & 83 \\
\hline IS 3 & 348 & 122 & 49 & 334 & 156 & 74 \\
\hline IBC & $3.68 \times 10^{4}$ & $\underset{5}{1.04 \times 10}$ & $6.7 \times 10^{5}$ & $3.27 \times 10^{4}$ & $\frac{1.57 \times 10}{5}$ & $7.6 \times 10^{5}$ \\
\hline ES 1 & 246 & 44 & 23 & 220 & 91 & 17 \\
\hline ES 2 & 273 & 62 & 18 & 189 & 86 & 28 \\
\hline ES 3 & 288 & 47 & 34 & 194 & 66 & 24 \\
\hline $\mathrm{EBC}$ & $2.69 \times 10^{4}$ & $5.1 \times 10^{4}$ & $2.5 \times 10^{5}$ & $2.01 \times 10^{4}$ & $8.1 \times 10^{4}$ & $2.3 \times 10^{5}$ \\
\hline
\end{tabular}

\section{Genotypic Identification}

Biochemical test assisted in the identification of bacteria isolated from the inlet and outlet of the anaerobic digester. Their interaction on different medium and preview of previous studies were significant to classify, and determine the identity of each colony [16]. The PCR analysis therefore confirmed the identity of the isolated strains. Molecular methods can identify DNA originating from many genera, containing pathogenic species and virulence genes [17]. Four (4) pathogenic bacteria strains (Azomonas spp., Aeromonas hydrophila, Salmonella spp., E. coli) were identified from influent WWW sample and one (1) from the effluent (Enterococcus faecalis) (Table IV, Fig. 6 and 7). According to Yergeau et al. [17], bacterial pathogens of concern that may be present in sewage are Salmonella spp., E. coli pathogenic strains, and $C$. jejuni. The sludge was less contaminated with large number of harmful bacteria colonies; albeit abundant with methanogens responsible for biogas 
M 1a

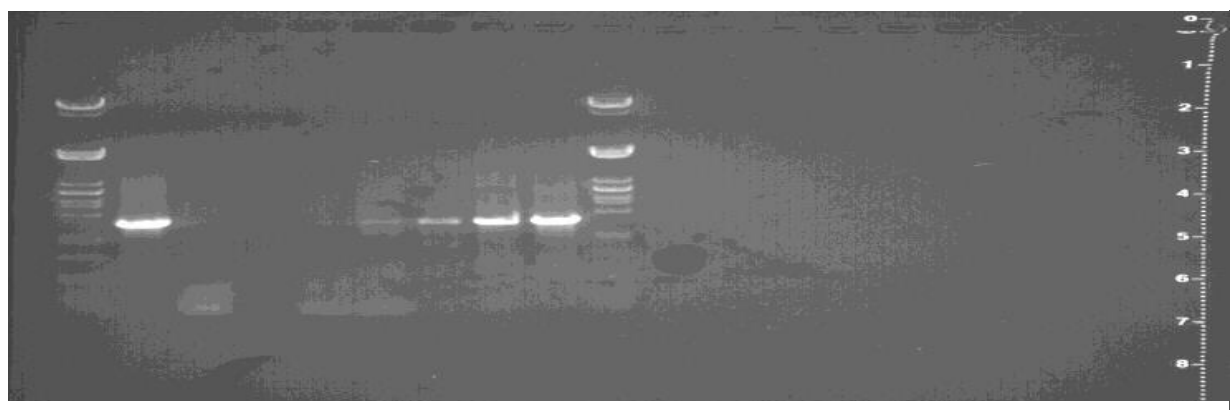

Fig.6. PCR for detection of bacteria from inlet of anaerobic digester

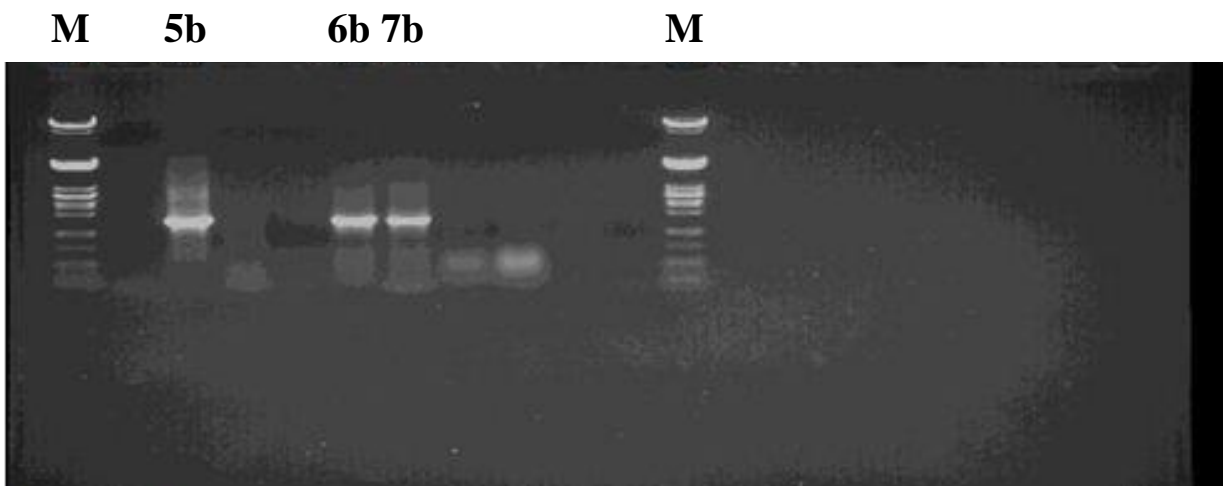

Gel 1 Legend:

M: Molecular weight marker

1a: Strain 1

2a: Strain 3

3a: Strain 4

4a: Strain 5

8a: E. coli VRBA

Fig.7. PCR for detection of bacteria from outlet of anaerobic digester

production. The rRNA based analysis is a fundamental technique in exploring the microbial diversity and to identify of strains [18], [19].

\section{TABLE IV: BACTERIA STRAINS IN THE INLET AND OUTLET OF ANAEROBIC DIGESTER}

\begin{tabular}{ccc}
\hline Strains & Influent & Effluent \\
\hline $\mathbf{1}$ & Azomonas spp & - \\
$\mathbf{2}$ & Azomonas spp & - \\
$\mathbf{3}$ & Aeromonas & - \\
& hydrophila & \\
$\mathbf{4}$ & Salmonella spp & - \\
$\mathbf{5}$ & Escherichia coli & - \\
& and VRBA & \\
$\mathbf{6}$ & - & Enterococcus faecalis \\
$\mathbf{7}$ & - & Methanobrevibacter $s p p$ \\
$\mathbf{8}$ & - & Methanosarcina $\mathrm{spp}$ \\
$\mathbf{9}$ & - & Methanosarcina spp \\
\hline
\end{tabular}

\section{E. Removal Efficiency of Pathogens in Anaerobic Digester}

The identity of bacteria found in the influent and effluent (Table IV), helped in measuring the efficiency in the reduction of surrogate bacteria. It was observed that process validation of the anaerobic digester designed and used in this study, was well established in the removal of some waterborne pathogens in the influent; meanwhile the result obtained were less satisfactory due to the presence of one gastrointestinal indicator, Enterococcus faecalis found in the effluent. Fig. 8 and 9 showed the effectiveness in the reduction of pathogen concentration on both the influent and effluent. In $1 \mathrm{~mL}$, higher reduction was noticed between the last 2 dilutions; with a 1.36 of margin. Although in $0.1 \mathrm{~mL}$, approximately 0.67 of margin removal was observed between each dilution with efficiency results. The $3 \log$ removal of E. coli, Salmonella spp., Azomonas spp., and Aeromonas hydrophila was obtained after 30 days of the process operation. However, strains of Enterococcus faecalis, Methanobrevibacter spp.; and Methanosarcina spp. were observed in the effluent sludge. Enterococcus spp. was low in concentration and its reduction was estimated at $1 \log$ with Methanosarcina spp. colonies being observed. Although further process such as recycling of the sludge will be needed to completely remove these pathogenic organisms (Enterococcus spp.).

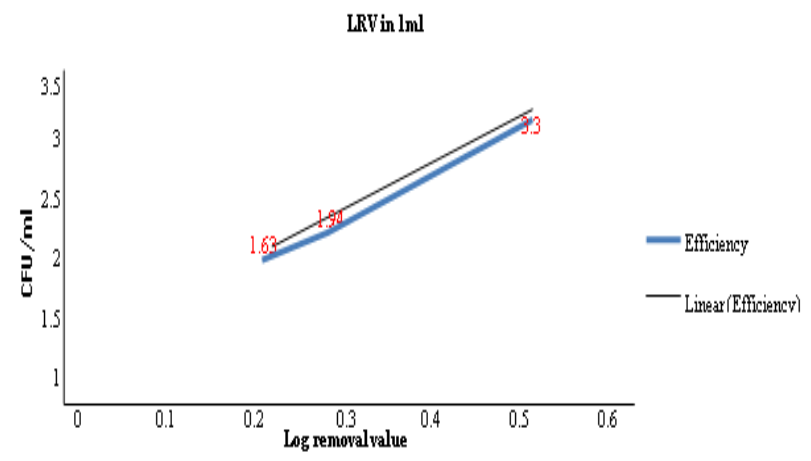

Fig. 8. Log removal value efficiency in $1 \mathrm{ml}$ of influent versus effluent 


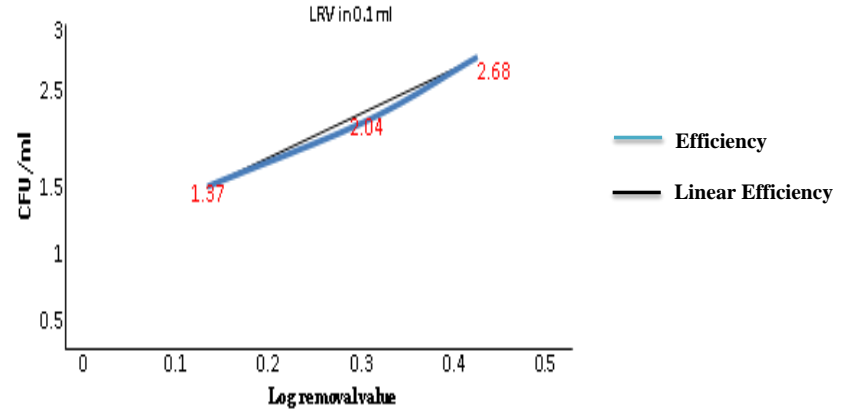

Fig. 9. Log removal value efficiency in $0.1 \mathrm{ml}$ of influent versus effluent

\section{CONCLUSION}

In this study, the reduction of target pathogen indicator microorganisms, such as E. coli, Enterococcus faecalis, and Salmonella spp. were studied. It can be concluded from this study that the pathogen reduction was achieved in the anaerobic digestion plant at ARC Nietvoorbij farm, Stellenbosch. The concentration of these surrogate microorganisms has been significantly reduced during the process of biogas production using the designed anaerobic digester. Overall, 3log removal efficiency of Escherichia coli, Salmonella spp., Azomonas spp. and Aeromonas hydrophila was obtained after 30 days.

\section{ACKNOWLEDGMENT}

This work is based on the research supported in part by the National Research Foundation of South Africa for the Thuthuka Unique Grant No. 99393. We are grateful to Mrs. Mmabatho Mobo and Mr. Micheal Tobin of the Department of Biotechnology for their technical assistant. We also thank Dr. Nike Lewu and Dr. Reckson Mulidzi of ARC, Infruitec Nietvoorbij farm, Stellenbosch, South Africa for their assistance and support.

\section{REFERENCES}

[1] C. S. Crockett, "The role of wastewater treatment in protecting water supplies against emerging pathogens. Water Environment Research," vol. 79, no. 3, pp. 221-232, March 2007. https://doi.org/10.2175/106143006X111952

[2] O. B. Akpor, and M. Muchie, "Environmental and public health implications of wastewater quality. African Journal of Biotechnology," vol. 10, no. 3, pp. 2379-2387, March 2011.

[3] P. Gaydon, N. Mcnab, G. Mulder, I. Pillay, M. Sahibdeen, and P. Thompson (January 2007). Evaluation of Sewage Treatment Package Plants for Rural, Peri-Urban and Community Use: WRC Report No. 1539/1/06 [Online] Pp.1-133.Available: http://www.wrc.org.za/Knowledge\%20Hub\%20Documents/Research\%2 0Reports/1539-1-06.pdf.

[4] I. Tirodimos, M. Arvanitidou, T. Dardavessis, A. Bisiklis, and S. Alexiou-Daniil., "Prevalence and antibiotic resistance of Pseudomonas aeruginosa isolated from swimming pools in northern Greece," Eastern Mediterranean Health Journal, vol. 16, no. 7, pp. 783-787, July 2010 https://doi.org/10.26719/2010.16.7.783

[5] I. Bodik, B. Herdova, and M. Drtil, "Anaerobic treatment of the municipal wastewater under psychrophilic conditions," Bioprocess Engineering, vol. 22, no. 5, pp. 385-390, May 2000. https://doi.org/10.1007/s004490050748

[6] A. Di Pinto, V. Terio, P. Di Pinto, and G. Tantillo, "Detection of potentially pathogenic Aeromonas isolates from ready-to-eat seafood products by PCR analysis," International Journal of Food Science and Technology, vol. 47, pp. 269-273, Nov. 2012.

https://doi.org/10.1111/j.1365-2621.2011.02835.x

[7] Dr L Godfrey. (October 2014). Department of Science and Technology Council for Scientific and Industrial Research (CSIR), Economic value of South Africa's waste (preliminary): A waste research, development and innovation (RDI) Roadmap capabilities at South African Universities and Science Councils, pp. 1-21 [Online]. Available: https://www.wasteroadmap.co.za/download/waste_rdi_capabilities_201 4.pdf.

[8] APHA. (November 2017). Standard methods for the examination of water and wastewater: 23rd edn. American Public Health Association, Washington, DC, pp. 1020-10900. [Online] Available: https://www.standardmethods.org/ViewArticle.cfm?articleID=113.

[9] E. O. Igbinosa, and A. I. Okoh, "Impact of discharge wastewater effluents on the physic-chemical qualities of a receiving watershed in a typical rural community," International Journal of Environmental Science \& Technology, vol. 6, no. 6, pp. 175-182, March 2009. https://doi.org/10.1007/BF03327619

[10] R. A. Deshmukh, K. Joshi, S. Bhand, and U. Roy, "Recent developments in detection and enumeration of waterborne bacteria: a retrospective minireview," MicrobiologyOpen, vol. 5, no. 6, pp. 901-922, Dec. 2016. https://doi.org/10.1002/mbo3.383

[11] H. Sirén, K. Sirén, and J. Sirén, "Evaluation of organic and inorganic compounds levels of red wines processed from Pinot Noir grapes," Analytical Chemistry Research, vol. 3, pp. 26-36, March 2015. https://doi.org/10.1016/j.ancr.2014.10.002

[12] X. Dai, H. Yan, N. Li, J. He, Y. Ding, L. Dai, and B. Dong, "Metabolic adaptation of microbial communities to ammonium stress in a high solid anaerobic digester with dewatered sludge," Scientific Reports, vol. 6, no. 28193, pp. 1-10, June 2016. https://doi.org/10.1038/srep28193

[13] S. J. Lawrence. (February 2012). Escherichia coli Bacteria Density in Relation to Turbidity, Streamflow Characteristics, and Season in the Chattahoochee River near Atlanta, Georgia, October 2000 through September 2008-Description, Statistical Analysis, and Predictive Modeling. U.S. Geological Survey Scientific Investigations Report: 2012-5037 [Online]. Pp. 1-81. Available: http://pubs.usgs.gov/sir/2012/5037/.

[14] J. M. Kayembe, F. Thevenon, A. Laffite, P. Sivalingam, P. Ngelinkoto, C. K. Mulaji, J. P. Otamonga, J. I. Mubedi, J. Poté, "High levels of faecal contamination in drinking groundwater and recreational water due to poor sanitation, in the sub-rural neighbourhoods of Kinshasa, Democratic Republic of the Congo," International Journal of Hygiene and Environmental Health, vol. 221, no. 3, pp. 400-408, April 2018. https://doi.org/10.1016/j.ijheh.2018.01.003

[15] N. J. Ashbolt, "Methods to identify and enumerate frank and opportunistic bacterial pathogens in water and biofilms," in Heterotrophic Plate Counts and Drinking-water Safety, J. Bartram, J. Cotruvo, M. Exner, C. Fricker, A. Glasmacher, Ed.World Health Organization (WHO), 2003, pp. 147- 169.

[16] D. H. Bergey and J. G. Holt J G. (January1994). Bergey"s manual of determinative bacteriology: Pp. 1-787 [Online]. Available: http://cput.worldcat.org/title/bergeys-manual-of-determinative-bacteriol ogy/oclc/28183643.

[17] E. Yergeau, L. Masson, M. Elias, S. Xiang, E. Madey, H. Huang, B. Brooks, L. A. Beaudette, "Comparison of Methods to Identify Pathogens and Associated Virulence Functional Genes in Biosolids from Two Different Wastewater Treatment Facilities in Canada," PLoS ONE, vol. 11, no. 4, pp. 1-20, April 2016. https://doi.org/10.1371/journal.pone.0153554

[18] G. Muyzer, and K. Smalla, "Application of denaturing gradient gel electrophoresis (DGGE) and temperature gradient gel electrophoresis (TGGE) in microbial ecology," Antonie van Leeuwenhoek, vol. 73, no. 1, pp. 127-141, Jan. 1998 https://doi.org/10.1023/A:1000669317571

[19] M. S. K. Mahmoud, "Characterization and Molecular Identification of Unknown Bacteria Isolated From Outlet of Arab El Madabegh Sewage Treatment Plant in Assiut City, Egypt," Journal of Ecology of Health \& Environment, vol. 4, no. 1, pp. 1-5 Jan. 2016. 
10th Int'I Conference on Advances in Science, Engineering, Technology \& Healthcare (ASETH-18) Nov. 19-20, 2018 Cape Town (South Africa)

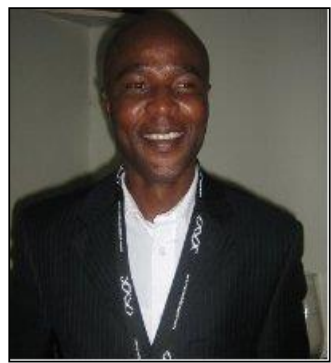

Dr. Vincent I. Okudoh completed his MSc

and $\mathrm{PhD}$ in Industrial Microbiology at the

University of KwaZulu-Natal (UKZN),

South Africa in 2011. Up till 2013, he was a

Postdoctoral Research Fellow and a member

of the African Energy, Food and Water

Research (AEFWR) group under Prof

Cristina Trois where he initiated a study on

the quantification of cassava biomass as

potential feedstock for biogas production. $\mathrm{He}$

joined the Cape Peninsula University of

Technology (CPUT) as a Lecturer in 2013 and currently a Senior Lecturer in the

Department of Biotechnology. 